\title{
CHARACTERIZATION AND ANTIOXIDANT ACTIVITY OF CASHEW NUT BRAN IN DIFFERENT STAGES OF PROCESSING
}

\author{
DENISE JOSINO SOARES* \\ CRISTIANE RODRIGUES SILVA CÂMARA** \\ EVÂNIA ALTINA TEIXEIRA DE FIGUEIREDO*** \\ GERALDO ARRAES MAIA**** \\ PAULO HENRIQUE MACHADO DE SOUSA***** \\ RAIMUNDO WILANE DE FIGUEIREDO******
}

\begin{abstract}
The present work aimed to characterize the cashew nut bran during several stages of processing, with emphasis in the quantification of total extractable polyphenols and total antioxidant activity. The cashew nut bran was analyzed for the following parameters: water activity, total acidity, $\mathrm{pH}$, moisture, ash, lipids, proteins, carbohydrates, total extractable polyphenols and total antioxidant activity by the methods ABTS ${ }^{+}$ and $\mathrm{DPPH}^{\circ}$. There was a decrease in the water activity and moisture in cashew nut bran during processing. The highest values of total extractable polyphenols and antioxidant activity were observed in raw bran due to peel adhered in these nuts.
\end{abstract}

* Doutoranda em Ciência e Tecnologia de Alimentos, Universidade Federal do Ceará (UFC), Fortaleza, CE (e-mail: denisejosino@hotmail.com).

** Mestre em Ciência e Tecnologia de Alimentos, Universidade Federal do Ceará (UFC), Fortaleza, CE (e-mail: nutcris@hotmail.com).

*** Doutora em Ciências Biológicas, Professora, Departamento de Tecnologia de Alimentos, UFC, Fortaleza, CE (e-mail: evania@ufc.br).

**** PhD em Ciência dos Alimentos, Professor Emérito, Departamento de Tecnologia de Alimentos, UFC, Fortaleza, CE (e-mail: garraes@pq.cnpq.br).

***** Doutor em Ciência e Tecnologia de Alimentos, Professor, Instituto de Cultura e Arte, UFC, Fortaleza, CE (e-mail: phenriquemachado@gmail.com).

******Doutor em Ciência dos Alimentos, Professor, Departamento de Tecnologia de Alimentos, UFC, Fortaleza, CE (e-mail: figueira@ufc.br). 


\section{INTRODUCTION}

The cashew tree belongs to Anacardiaceae family (LIMA et al., 2007). Among the products of the cashew tree, cashew nut stands out as the most important on the economic standpoint (LIMA and DUARTE, 2006).

According to IBGE data (2012), Brazil produced 104.342 tons of cashew nuts in 2010. With this high production, Brazil is the third largest producer and the second largest exporter of cashew nut in the world (ANDRADE NETO, 2006).

Cashew nut processing can be performed in three ways: manual, semi-mechanized and mechanized. These processes differ in the type of operation used in the shelling step. The processing of cashew nuts includes the following steps: harvesting of cashew, removal of the cashew nut, cleaning, selection, first drying, classification, cooking, shelling, second drying, cooling, peeling, packing and storage (PAIVA, SILVA NETO \& PESSOA, 2000).

The mechanized process generates about $40 \%$ of broken nuts, however, when manually processed this value is reduced for approximately $20 \%$ (LIMA and DUARTE, 2006).

A standard classification was established to facilitate the commercialization of whole and broken cashew nuts. According to Oliveira and Costa (2005), the cashew nuts can be sorted by group, class and type.

During the processing of fruits losses of some compounds may occur and there are few studies on this aspect regarding cashew nut. It is important to assess these losses (TUDELA, ESPÍN and GIL, 2002; ZHANG and HAMAUZU, 2004) to providing a better protection of the important components.

The consumption of fruit and vegetables has increased due to the high functional value of these products since they are source of micronutrients, fiber and other functional components. This type of food is important to prevent cardiovascular diseases and some types of cancer (LOCK et al., 2005).

Cashew nut has high content of phenolic compounds (NACZK and SHAHIDI, 2006), in vitro antioxidant activity (AMICO et al., 2006) and cardio protective effect (HEIM, TAGLIAFERRO and BOBILYA, 2002). The consumption of nuts has been associated with the reduction of cardiovascular diseases (KELLY JÚNIOR and SABATÉ, 2006).

This research aims to characterize the cashew nut bran during several stages of processing, emphasizing the quantification of total extractable polyphenols and total antioxidant activity.

\section{MATERIAL AND METHODS}

This study was performed with cashew nuts bran given by a large company in the city of Fortaleza, Ceará (Brazil).

The cashew nut bran was collected at three stages of processing: reception of raw bran, before cooking and during cooling. These stages of processing were selected to identify possible losses regarding the chemical and physicochemical characteristics and in the antioxidant activity during the nut processing.

The bran was collected in plastic bags and then crushed in a domestic blender at the time of analysis which consisted of: water activity, total acidity (IAL, 2008), pH (IAL, 2008), moisture (IAL, 2008), lipids (IAL, 2008), protein (AOAC, 1995), ash (AOAC, 1996), total extractable polyphenols (TEP) (LARRAURI, RUPEREZ and SAURA-CALIXTO, 1997) and the total antioxidant activity testing by the free radicals $A B T S^{++}$(2,2'-Azino-bis(3-ethylbenzothiazoline-6-sulfonic acid) diammonium salt) (RE et al., 1999) and DPPH' (2,2-Diphenyl-1-picrylhydrazyl) (BRAND-WILLIANS, CUVELIER and BERSET, $1995)$ assays. The total carbohydrates were estimated by the difference between the percentage of centesimal composition and the sum of the moisture, ash, lipids and proteins percentage.

The water activity was determined by direct reading of the samples, using the digital 
Higrotermo 95.

For the determination of the total acidity, $1 \mathrm{~g}$ of cashew nut bran diluted in $50 \mathrm{~mL}$ of water was used. The titration was performed with $\mathrm{NaOH}(0.1 \mathrm{~N})$ and phenolphthalein $1 \%$ as indicator.

The $\mathrm{pH}$ was measured directly using $1 \mathrm{~g}$ of cashew nut bran diluted in $50 \mathrm{~mL}$ of water, and moisture was determined by the direct heating in the oven $\left(121^{\circ} \mathrm{C}\right)$ of $2.5 \mathrm{~g}$ of cashew nut bran until the constant weight was obtained.

The lipids were extracted in Soxhlet apparatus, using hexane as solvent.

The content of proteins was measured by micro-Kjeldahl method.The protein-nitrogen conversion factor used to estimate the protein level was 6.25 .

The ash was determined in a muffle furnace at $550^{\circ} \mathrm{C}$, using $2.5 \mathrm{~g}$ of crushed cashew nut.

The extract for the TEP and total antioxidant activity quantification was prepared using the defatted bran. According to Alasalvar et al. (2006), the components with antioxidant activity are efficiently extracted using defatted samples.

The process to remove the fat was performed according to Cavalcante (2010) and consisted of weighing $10 \mathrm{~g}$ of bran and adding $20 \mathrm{~mL}$ of hexane followed by agitation of the solution for 20 minutes in a magnetic stirrer and subsequent centrifugation at $3000 \mathrm{rpm}$ for 15 minutes. The residue was placed under a hood for complete evaporation of the hexane. The extract was prepared according to Larrauri, Ruperez and Saura-Calixto (1997), using ethanol $50 \%$ and acetone $70 \%$ and centrifugations at $3000 \mathrm{rpm}$ for 15 minutes.

For the determination of the antioxidant activity by $\mathrm{ABTS}^{++}$and $\mathrm{DPPH}^{\cdot}$ assays, the extract was used with the following concentrations: 4000, 8000, 12000 and $16000 \mathrm{ppm}$ for bran collected at the step of reception and 25000, 50000, 100000 and 200000 ppm for bran collected before the cooking and in the cooling steps.

The reading was done using a spectrophotometer (SHIMADZU UV - 1800) at $734 \mathrm{~nm}, 6$ minutes after the addition of the solution of $\mathrm{ABTS}^{\circ+}$ at $0,700 \pm 0.05$ of absorbance. The DPPH assay was performed 30 minutes after the addition of the ethanolic solution of $\mathrm{DPPH} \cdot 0.06 \mathrm{mM}$.

The experiment was conducted in a Completely Randomized Design, using three treatments (steps of the processing line) and three replicates. The results were statistically evaluated by variance analysis (ANOVA). When significant difference was verified by the $F$ test, the treatments were compared by Tukey test at $5 \%$ probability using the program Statistica 7 (STATSOFT, 2004).

\section{RESULTS AND DISCUSSION}

The highest values for water activity (Aw) were found in bran collected on the steps of reception of raw bran $(0.54)$ and before the cooking $(0.55)$, differing significantly $(p<0.05)$ of water activity observed in the cooling (Table 1 ). The decrease of water activity was expected, since high temperatures are used at the cooking step, which causes loss of water in the bran.

TABLE 1 - MEAN VALUES OF WATER ACTIVITY, TOTAL ACIDITY AND PH OF CASHEW NUT BRAN IN DIFFERENT STAGES OF PROCESSING*

\begin{tabular}{cccc}
\hline Collection stages & Water activity & $\begin{array}{c}\text { Total acidity } \\
\text { (g oleic acid } / 100 \mathrm{~g})\end{array}$ & $\mathrm{pH}$ \\
\hline Reception of raw bran & $0.54^{\mathrm{a}}$ & $0.99^{\mathrm{a}}$ & $6.37^{\mathrm{a}}$ \\
Before the cooking & $0.55^{\mathrm{a}}$ & $0.88^{\mathrm{a}}$ & $6.45^{\mathrm{a}}$ \\
Cooling & $0.45^{\mathrm{b}}$ & $0.99^{\mathrm{a}}$ & $6.33^{\mathrm{a}}$ \\
\hline
\end{tabular}

* Same letters within the same column are not statistically different by Tukey test $(p \leq 0.05)$. 
The result for water activity in raw cashew nut was lower than those reported at study performed by Cavalcante (2010) in which was observed water activity of 0.75 in cashew nut collected at the reception step, which can be justified by the high surface in the bran, allowing greater heat penetration and greater loss of water during drying step.

The total acidity values ranged from 0.88 (before cooking) to $0.99 \mathrm{~g}$ oleic acid/100 g (reception of raw bran and in the cooling), no significant difference $(p>0.05)$ was found among the studied steps.

In the same way as total acidity, the $\mathrm{pH}$ values did not differ significantly among the studied steps (Table 1). Similar results were found by Cavalcante (2010), who reported pH of 6.57 in cashew nut.

In the same way as water activity, the moisture was higher in bran collected at the steps before cooking. This reduction occurs due to drying step. It was observed significant difference $(p<0.05)$ among the collected stages (Table 2).

\section{TABLE 2 - MEAN VALUES OF MOISTURE, ASH, LIPIDS, PROTEIN AND CARBOHYDRATES OF CASHEW NUT BRAN IN DIFFERENT STAGES OF PROCESSING*}

\begin{tabular}{cccccc}
\hline Collection stages & $\begin{array}{c}\text { Moisture } \\
(\%)\end{array}$ & $\begin{array}{c}\text { Ash } \\
(\%)\end{array}$ & Lipids (\%) & $\begin{array}{c}\text { Protein } \\
(\%)\end{array}$ & $\begin{array}{c}\text { Carbohydrates } \\
(\%)\end{array}$ \\
\hline Reception of raw bran & $5.67^{\mathrm{a}}$ & $2.38^{\mathrm{a}}$ & $38.29^{\mathrm{a}}$ & $14.28^{\mathrm{a}}$ & $39.36^{\mathrm{a}}$ \\
Before the cooking & $5.10^{\mathrm{b}}$ & $2.50^{\mathrm{a}}$ & $38.70^{\mathrm{a}}$ & $15.62^{\mathrm{a}}$ & $38.08^{\mathrm{a}}$ \\
Cooling & $2.65^{\mathrm{c}}$ & $2.56^{\mathrm{a}}$ & $41.22^{\mathrm{a}}$ & $15.26^{\mathrm{a}}$ & $38.28^{\mathrm{a}}$ \\
\hline
\end{tabular}

* Same letters within the same column are not statistically different by Tukey test $(p \leq 0.05)$.

Cavalcante (2010) and Lima and Borges (2004) characterized cashew nuts and found moisture values of 2.98 and $3.29 \%$, respectively, presenting lower results than those verified in the present study.

Lower percentages of moisture are ideal for the best conservation and acceptance of nuts. Low values of moisture can inhibit the microorganism growth and avoid undesirable alterations in the texture.

The ash percentage ranged from 2.38 (reception of raw bran) to $2.60 \%$ (cooling). These results are similar to those reported by Cavalcante (2010), FAO (2010) and Venkatachalam and Sathe (2006) that observed ash values of $2.48,2.40$ and $2.66 \%$, respectively.

The highest amount of lipids was $41.22 \%$ (in bran collected in the cooling step) and did not present significant difference $(p>0.05)$ from the other steps (Table 2$)$. Similar results were reported by Abe, Lajolo and Genovese (2010), that observed lipids percentages of $42 \%$ in cashew nut and lower than determined by FAO (2010) which is $46 \%$.

The maximum percentage of protein was $15.62 \%$ which is lower than that reported by FAO (2010) and Venkatachalam and Sathe (2006) in cashew nut being $24 \%$ and $18.81 \%$, respectively.

The estimate about the carbohydrate content in bran nut presented results close to those determined by FAO (2010) that indicates that cashew nut must have $41 \%$ of carbohydrates.

The total extractable polyphenols content was higher in raw bran $(401.95 \mathrm{mg}$ of gallic acid equivalent (GAE)/100 g) (Table 3), which can be explained by the fact that the membrane that covers the nut is rich in phenolic compounds and it is only removed in later steps. According to Blomhoff et al. (2006), most phenolic compounds are present in the membrane and less than $10 \%$ is retained on the almonds when it is removed. 


\section{TABLE 3 - MEAN VALUES OF TOTAL EXTRACTABLE POLYPHENOLS AND THE TOTAL ANTIOXIDANT ACTIVITY TESTING BY THE FREE RADICALS ABTS ${ }^{++}$AND DPPH' OF CASHEW NUT BRAN IN DIFFERENT STAGES OF PROCESSING*}

\begin{tabular}{cccc}
\hline Collection stages & TEP & ABTS ${ }^{+}$ & $\mathrm{DPPH}^{\cdot}$ \\
& $(\mathrm{mg} \mathrm{GAE} / 100 \mathrm{~g})$ & $(\mu \mathrm{M}$ Trolox/g $)$ & $(\mathrm{g} / \mathrm{g} \mathrm{DPPH})$ \\
\hline Reception of raw bran & $401.95^{\mathrm{a}}$ & $26.99^{\mathrm{a}}$ & $2962.17^{\mathrm{b}}$ \\
Before the cooking & $127.24^{\mathrm{b}}$ & $8.29^{\mathrm{b}}$ & $12927.07^{\mathrm{a}}$ \\
Cooling & $102.06^{\mathrm{b}}$ & $5.27^{\mathrm{b}}$ & $11311.94^{\mathrm{a}}$ \\
\hline
\end{tabular}

* Same letters within the same column are not statistically different by Tukey test $(p \leq 0.05)$.

As verified in the polyphenols content, the highest values of antioxidant activity were observed in the raw bran. There was no significant difference $(p>0.05)$ for the content of polyphenols and antioxidant activity by $\mathrm{ABTS}^{+}$and $\mathrm{DPPH}^{*}$ assays among the bran collected in steps before the cooking and in the cooling (Table 3 ), indicating that the loss of these components is related to the removal of the film.

The highest antioxidant activity by ABTS ${ }^{++}$assay was $26.99 \mu \mathrm{M}$ Trolox/g of bran. Different results were reported by Cavalcante (2010), for analysis of raw cashew nuts using the same analytical conditions and value of $13.55 \mu \mathrm{M}$ Trolox/g of almonds was observed. This variation may be due to the amount of film attached to the nut.

The lowest value observed in the DPPH assay was related to raw bran $(2962.17 \mathrm{~g} / \mathrm{g}$ of $\mathrm{DPPH}^{\circ}$ ), indicating a higher antioxidant activity in this step, which is consistent, because in the DPPH' assay, the results are expressed according to the quantity of bran required to reduce $50 \%$ of the initial concentration of $\mathrm{DPPH} \cdot$ radical, so the lower result by the $\mathrm{DPPH}^{\cdot}$ assay, the greater antioxidant activity in the sample.

\section{CONCLUSION}

It was observed reduction on the water activity and moisture in bran during the processing.

The highest values of total extractable polyphenols and antioxidant activity were observed in the raw bran probably due to the greater amount of film attached at the bran at this stage.

\section{RESUMO}

\section{CARACTERIZAÇÃO E ATIVIDADE ANTIOXIDANTE DO FARELO DE CASTANHA DE CAJU EM DIFERENTES ETAPAS DO PROCESSAMENTO}

O presente trabalho teve como objetivo caracterizar o farelo da castanha de caju em diferentes etapas de processamento, com ênfase na quantificação dos polifenois extraíveis totais e da atividade antioxidante. $O$ farelo da castanha de caju foi analisado quanto aos seguintes parâmetros: atividade de água, acidez total, $\mathrm{pH}$, umidade, cinzas, lipídios, proteínas, carboidratos, polifenois extraíveis totais e atividade antioxidante pelos métodos $\mathrm{ABTS}^{+}$e DPPH: Verificou-se redução na atividade de água e na umidade do farelo de castanha de caju durante o processamento. Os maiores valores de polifenois extraíveis totais e da atividade antioxidante foram observados na amêndoa crua, devido à película aderida nesses farelos.

PALAVRAS-CHAVE: AMÊNDOA DE CASTANHA DE CAJU - RESÍDUO; COMPOSTOS BIOATIVOS; APROVEITAMENTO DE RESÍDUOS. 


\section{REFERENCES}

1 ABE, L. T.; LAJOLO, F. M.; GENOVESE, M. I. Comparison of phenol content and antioxidant capacity of nuts. Ciência e Tecnologia de Alimentos, v. 30, s. 1, p. 254-259, 2010.

2 ALASAVAR, C.; KARAMACÄ, M.; AMAROWICZ, R.; SHAHIDI, F. Antioxidant and antiradical activities in extracts of hazelnut. Journal of Agricultural and Food Chemistry, v. 54, n. 13, p. 4826-4832, 2006.

3 AMICO, V.; BARRESI, V.; CONDORELLI, D.; SPATAFORA, C.; TRINGALI, C. Antiproliferative terpenoids from almond hulls (Prunus dulcis): identification and structure-activity relationships. Journal of Agricultural and Food Chemistry, v. 54 , n. 3, p. 810-814, 2006.

4 ANDRADE NETO, J. C. de. Competitividade na pequena produção industrial: estudo da agroindústria da castanha de caju. 2006. 91 f. Dissertação (Mestrado em Ciências em Engenharia de Produção) - Universidade Federal do Rio Grande do Norte, Natal, 2006

5 AOAC. Association of Official Analitical Chemistry. Official methods of analysis of the AOAC International. $16^{\text {th }}$ ed. Washington, D. C. 1995. $1141 \mathrm{p}$

6 AOAC. Association of Official Analitical Chemistry. Official methods of analysis of the AOAC International. $17^{\text {th }}$ ed. Arlington, 1996. Chapter 44. p.3.

7 BLOMHOFFI, R.; CARLSEN, M. H.; ANDERSEN, L. F.; JACOBS JÚNIOR, D. R. Health benefits of nuts: potential role of antioxidants. British Journal of Nutrition, v. 96, s. 2, p. 52-60, 2006.

8 BRAND-WILLIANS, W. CUVELIER, M. E.; BERSET, C. Use of free radical method evaluate antioxidant activity. Food Science and Technology, v. 28, n. 1, p. 25-30. 1995.

9 CAVALCANTE, C.E.B. Atividade antioxidante total durante o processamento de amêndoas de castanha de caju (Anacardium ocidentale L.). 2010. 87 f. Dissertação (Mestrado em Ciência e Tecnologia de Alimentos), Universidade Federal do Ceará, Fortaleza, 2010.

10 FAO. Food and Agriculture Organization of the United Nations. Integrated production practices of cashew in Asia. [online]. Available at: http://www.fao.org/docrep/005/ac451e/ac451e0b.htm Accessed on: 06 April 2010.

11 HEIM, K. E.; TAGLIAFERRO, A. R.; BOBILYA, D. J. Flavonoid antioxidants: chemistry, metabolism and structure-activity relationships. The Journal of Nutritional Biochemistry, v. 13, n. 10, p. 572-584, 2002.

12 IAL. Instituto Adolfo Lutz. Métodos físico-químicos para análise de alimentos. 6. ed. São Paulo, 2008.1020 p.

13 IBGE. Instituto Brasileiro de Geografia e Estatística. Produção agrícola nacional. Tabela: 1613 - Área plantada, área colhida, quantidade produzida e valor da produção da lavoura permanente. Available at: <htpp://www.sidra.ibge.gov.br>. Accessed on: 22 jun. 2012.

14 KELLY JÚNIOR, J. H.; SABATÉ, J. Nuts and coronary heart disease: an epididemiological perspective. British Journal of Nutrition, v. 96, s. 2, p. 61-6, 2006.

15 LARRAURI, J. A.; RUPEREZ, P.; SAURA-CALIXTO, F. Effect of drying temperature on the stability of polyphenols and antioxidant activity of red grape pomace peels. Journal of Agricultural and Food Chemistry, v. 45, n. 4, p. 1390-1393, 1997.

16 LIMA, E. S.; SILVA, E. G.; MOITA NETO, J. M.; MOITA, G. C. Redução de vitamina C em suco de caju (Anacardium occidentale L.) industrializado e cajuína. Química Nova, v. 30, n. 5, p. 1143-1146, 2007.

17 LIMA, J. R.; BORGES, M. F. Armazenamento de amêndoas de castanha de caju: influência da embalagem e da salga. Revista Ciência Agronômica, v. 35, p. 104-109, 2004.

18 LIMA, J. R.; DUARTE, E. A. Pastas de castanha-de-caju com incorporação de sabores. Pesquisa Agropecuária Brasileira, v. 41, n. 8, p. 1333-1335, 2006.

19 LOCK, K.; POMERLAU, J.; CAUSER, L.; ALTMANN, D. R.; MCKEE, M. The global burden of disease attributable to low consumption of fruit and vegetables: implications for the global strategy on diet. Bull. World Health Organ., v. 83, n. 2, p. 100-108, 2005.

20 NACZK, M.; SHAHIDI, F. Phenolics in cereals, fruits and vegetables: occurrence, extraction and analysis. Journal of Pharmaceutical and Biomedical Analysis, v. 41, n. 5, p. 1523-1542, 2006.

21 OLIVEIRA, V. H.; COSTA, V. S. O. Manual de produção integrada de caju. Fortaleza: Embrapa Agroindústria Tropical, 2005. 355 p.

22 PAIVA, F. F. A.; SILVA NETO, R. M.; PESSOA, P. F. A. P. Minifábrica de processamento de castanha de caju. Fortaleza: Embrapa Agroindústria Tropical, 2000. 22 p. 
23 RE, R.; PELLEGRINI, A. P.; PANNALA, A.; YANG, M.; RICE-EVANS, C. Antioxidant activity applying an improved ABTS radical cation decolorization assay. Free Radical Biology \& Medicine, v. 26, n. 9-10, p. 1231-1237, 1999.

24 STATSOFT, Inc. Statistica (Data Analysis Software System). Version 7. Tulsa, USA, 2004.

25 TUDELA, J. A.; ESPÍN, J. C.; GIL, M. I. Vitamin C retention in fresh-cut potatoes. Postharvest Biology and Technology, v. 26, n. 1, p. $75-84,2002$

26 VENKATACHALAM, M.; SATHE, S. K. Chemical composition of selected edible nut seeds. Journal of Agricultural and Food Chemistry, v. 54, n. 13, p. 4705-4714, 2006.

27 ZHANG, D.; HAMAUZU, Y. Phenolics, ascorbic acid, carotenoids and antioxidant activity of broccoli and their changes during conventional and microwave cooking. Food Chemistry, v. 88, n. 4, p. 503-509, 2004. 